\title{
The application of android-based geogebra on quadratic equations material toward mathematical creative thinking ability
}

\author{
Ari Septian', Rani Sugiarni', Erma Monariska1 \\ ${ }^{1}$ Universitas Suryakancana, Indonesia. \\ $\triangle$ ariseptian@unsur.ac.id
}

Article Information

Submitted Sept 01, 2020

Revised Oct 10, 2020

Accepted Oct 22, 2020

Keywords

Creative thinking ability;

Android-based GeoGebra;

Quadratic equation.

\begin{abstract}
Students' low creative thinking skills and difficulty in drawing graphs from the given algebraic equations are the background of this study. The purpose of this study was to determine the mathematical creative thinking abilities between Android-based GeoGebra and ordinary learning. This study also investigated students' responses to the application of Android-based GeoGebra. The research method used was quasi-experimental with a nonequivalent group pretest-posttest design. The instruments were a creative thinking test and a questionnaire. The subjects of this study were students of one of the junior high school in Cianjur selected by purposive sampling technique. The studied material was the quadratic equations as a part of algebra. The gain index data analysis technique used was the normality test and the Mann Whitney test while the questionnaire data responses were analyzed through the average percentage of students' answers. As a result, the students' mathematical creative thinking ability with Android-based GeoGebra was better than ordinary learning. Also, the students provided positive responses to the application of Android-based GeoGebra.
\end{abstract}

\section{INTRODUCTION}

In the current era of globalization, technology is developing rapidly, including the development of information and communication technology (Hendriawan \& Septian, 2019; Maskur et al., 2020). One of the developments of information and communication technology is the development of telecommunications technology, namely smartphones. The elementary school students (SD), junior high school students (SMP), and senior high school students (SMA) have used smartphones (Mulyani et al., 2019; Sanusi et al., 2020).

The smartphones owned by students can be used as a supporter of the learning process although it is far from expectations. Most students only use smartphones as mere social media (Sianturi \& A, 2019). Based on the observations and interviews conducted by researchers with some students, it can be concluded that very few of them used smartphones to support learning. This is a problem for the world of education where technological developments should be used to support the learning process (Putra et al., 2016; Septian, 2017).

In several previous studies, the improvements in students' mathematical creative thinking skills were caused by the use of the 2013 curriculum cooperative learning model, the use of media and multimedia wiSth Macromedia flash applications, and offline Geogebra (Alfian et al., 2017; Hu et al., 2016; Purwanti et al., 2016; Rudyanto, 2016; Septian et al., 2020). In this study, the application of Android-based GeoGebra has the advantage of visualizing equations in the algebraic form to graphical form (Budiman \& Ramdhani, 2017). The application of 
Android-based GeoGebra on mobile learning is still rarely used by teachers in schools (Arbain \& Shukor, 2015; Nanang, 2015). Likewise, the provision of material with Androidbased GeoGebra is still limited. The difference between this research and the previous research lies in the application of Android-based GeoGebra on Quadratic Equations and Drawing Quadratic Equations materials.

Many students do not know that learning with Android has been widely used and Android applications are very useful in learning and effective enough to access educational information (Hendriawan \& Septian, 2019; Pramuditya et al., 2018). Therefore, the use of android applications is expected to make it easier for students to accept and understand the subject matter (Pratama \& Haryanto, 2018). On the other hand, it also makes it easier for teachers to deliver subject matter (Septian et al., 2019; Sugiarni et al., 2018)

Students need communication skills, collaboration skills, critical thinking, and creative thinking ability in learning (Legowo et al., 2019; Nurlenasari et al., 2019). This shows that creative thinking abilities have become one of the important things in mathematics learning (Ainurrizqiyah et al., 2015; Suripah, S., 2017). This ability is not only a competency that must be taught to students but should be sought as much as possible in learning mathematics.

Students' mathematical creative thinking ability is still low (Wijayanti \& Sungkono, 2017). Based on the results of preliminary observations at SMPN 1 Cianjur, only $40 \%$ of 35 students can work on problems to measure mathematical creative thinking ability. This low ability can be influenced by errors in the way of learning (Lince, 2016). Each individual has a different way of learning. Each person cannot be forced to follow one way of learning. But in reality, many students do not realize which learning style is suitable for their personality. The learning style that is not suitable for the personality of students is what causes difficulty for them when facing complex and non-routine problems (Firdausi \& Asikin, 2018; Sriwongchai, 2015).

This problem is thought to be caused by a high level of thinking, including the creativethinking ability that is rarely trained because the learning process usually includes tasks with only 1 correct answer. Many students find it difficult to answer a simple problem, let alone to bring up ideas or new ways in the learning process (Muhammad et al., 2018). This makes students assume that mathematics is frightening and difficult.

It is necessary to apply a learning tool that can improve students' mathematical creative thinking ability. Efforts that can be made by teachers to improve these abilities are by applying learning media assistance (Nadz, 2013; Özyaprak, 2016; Sarah Sanders, 2016). Mobile-based learning strategies are more interactive, fun, and very effective in achieving learning objectives (Hockly, 2013; Sharples \& Pea, 2014). Through teaching media, students' creative thinking skills during the learning process, and their understanding are classified as good and have improved (Sugilar, 2013). Android-based GeoGebra can improve students' mathematical creative thinking ability. By implementing Android-based Geogebra as a learning medium, students can improve their creative mindset and add more advanced knowledge.

Besides, the Android-based GeoGebra can improve students' mathematics learning outcomes. There is a topic in mathematics that fosters the ability to think creatively among students in terms of quadratic equations (Sundari, 2017). Quadratic equation material is a material that is very interesting for students because this material can be applied directly in 
everyday life and is also widely used in calculus. Quadratic equations are also widely used in tests of academic potential. Based on the description that has been stated, this study was aimed to determine the improvement of mathematical creative thinking ability between Android-based GeoGebra and ordinary learning, as well as students' responses toward the application of Android-based GeoGebra.

\section{METHODS}

The method used was the quasi-experimental method with a quantitative approach which is the method used to see the influence of learning models (Creswell, 2007). The subjects of this study were students of one of the junior high school in Cianjur determined with the purposive sampling technique. The samples were 35 students from class IX B and 33 students from class IX F. The research design used was nonequivalent group pretest-posttest (Johnson, R. B., \& Christensen, 2014). The research design is presented in Figure 1.

\begin{tabular}{|lccccc|}
\hline & Pretest & \multicolumn{3}{c|}{ Treatment } & \multicolumn{2}{c|}{ Posttest } \\
& Measure & \multicolumn{3}{c}{ Measure } \\
Experimental Group: & $\mathrm{O}_{1}$ & & $\mathrm{X}_{1}$ & $\mathrm{O}_{2}$ \\
Control Group: $\mathrm{O}_{1}$ & & $\mathrm{X}_{2}$ & & $\mathrm{O}_{2}$ & \\
& & & & & \\
$\mathrm{X}_{1}$ : Android-based GeoGebra & & & & \\
$\mathrm{X}_{2}$ : Ordinary Learning & & & & & \\
\hline
\end{tabular}

Figure 1. Nonequivalent Group Pretest-Posttest Design

This study administered the test and non-test instruments. The test instrument was a creative thinking ability test and in the form of a written test consisting of a pretest and a posttest. The non-test instrument was in the form of a student questionnaire response to the application of Android-based GeoGebra. The instruments were tested for their validity, reliability, discriminating index, and difficulty level. The testing was done to determine the quality of items to be given. After that, the data obtained through tests of mathematical creative thinking ability was tested using the normality test and the Mann Whitney test while the questionnaire data response was analyzed by using the average percentage of student answers. The research flowchart is presented in Figure 2 


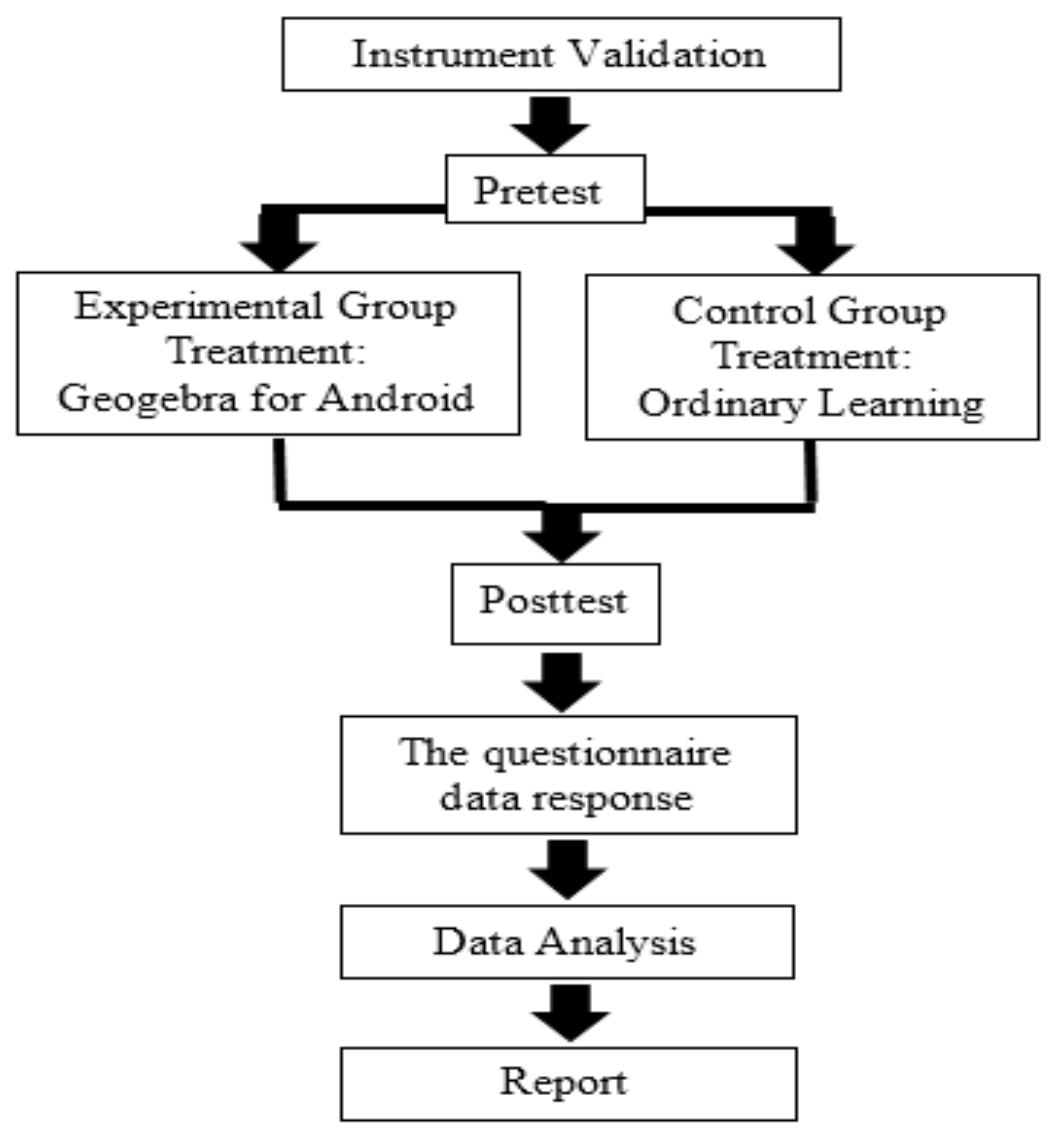

Figure 2. Research Flowchart

\section{RESULTS AND DISCUSSION}

\section{Improvements of the Mathematical Creative Thinking Ability}

Gain index data analysis was performed to determine the improvement of the mathematical creative thinking ability of the experimental class and control class after given different treatments. The experimental class applied the Android-based GeoGebra while the control class applied ordinary learning. The descriptive analysis of the gain index data was performed by utilizing SPSS 24. The results of the descriptive statistical analysis of the gain index of the experimental class and the control class are presented in Table 1.

Table 1. Descriptive Statistics of Gain Index Data

\begin{tabular}{lcc}
\multicolumn{1}{c}{ Class } & Experimental & Control \\
Average & 0.71 & 0.54 \\
Standard Deviation & 0.12 & 0.18 \\
Minimum & 0.29 & 0.27 \\
Maximum & 0.98 & 0.69 \\
\hline
\end{tabular}

Based on Table 1, the average score of the experimental class's gain index was greater than the average control class's gain index. However, to get more objective results and to find out whether the difference in the average gain index was significant or not, the data for the gain indexes of both classes must be tested with the normality test to find out whether the gain indexes obtained from the two classes were normally distributed or not and determine the statistical procedure to be used next. The normality test in this study was the Shapiro-Wilk 
test assisted by SPSS 24 software with a significance level of 5\% (0.05). The results of data processing are presented in Table 2.

Table 2. The Results of Normality Test on Gain Data Index Distribution

\begin{tabular}{lcl}
\multirow{2}{*}{ Class } & \multicolumn{2}{c}{ Shapiro-Wilk } \\
\cline { 2 - 3 } \multicolumn{1}{c}{ Experiment } & Sig. & \multicolumn{1}{c}{ Decision } \\
Control & 0.200 & Data are normally distributed \\
\hline
\end{tabular}

Based on Table 2, the significance value for the experimental class was 0.200 . since the significance value of the experimental class was more than 0.05 , then $\mathrm{H}_{0}$ was accepted. It can be concluded that the sample of the experimental class had been normally distributed. The control class obtained a significance value of 0.010. Since the significance value of the control class was less than 0.05 , then $\mathrm{H}_{0}$ was rejected. It can be concluded that the control class sample was not normally distributed. The data analysis was continued with the nonparametric statistical test, namely the Mann-Whitney test assisted by SPSS 22 software. The Mann-Whitney data processing results are presented in Table 3.

Table 3. The Results of Population Distribution Gain Index Data

$\begin{array}{cc}\text { Asymp. Sig. (2-tailed) } & \text { Decision } \\ 0.000 & H_{0} \text { is rejected }\end{array}$

Based on Table 3, the significance values for Asymp. Sig. (2-tailed) was 0,000. Since the significance value obtained was less than 0.05 , then $\mathrm{H}_{0}$ was rejected. Thus, it can be concluded that the mathematical creative thinking ability of students who studied with Android-based GeoGebra was better than students who studied with ordinary learning.

Based on the results of pretest data processing, the average score of the experimental class was higher than the control class although a relatively small difference. The data was strengthened by the Mann Whitney test which illustrated that there was no initial mathematical creative thinking ability difference between experimental class students and control class students. Therefore, the improvement of students' mathematical creative thinking ability can be seen from the results of the gain index data.

The data processing of the gain index of students' mathematical creative thinking ability illustrates that the mathematical creative thinking ability of the experimental class students was better than that of the control class. In other words, the improvement of students' mathematical creative thinking ability by applying the Android-based GeoGebra was better than students who applied the ordinary learning.

Android-based GeoGebra can improve students' creative thinking skills because it is flexible and easy to use (Hallal et al., 2016; Saputra \& Fahrizal, 2019). The advantage of Android-based GeoGebra is that students can directly use their cellphones to work on problems and try to flexibly change the points (Amalia et al., 2020). For example, changing or moving the existing pointer of an image. This is what makes students think more creatively and keep trying new things and then comparing them with the actual mathematical concept.

Indonesia needs creative workers who can make a meaningful contribution to the development of science and technology for the welfare of the nation (Noer, 2011; Zaheer et al., 2018). The creative-thinking ability needs to be improved. It is one of the abilities to think in mathematics. Creative is a mindset that can produce new methods, new concepts, new 
understandings, discoveries, and new works (Lince, 2016). Creative-thinking ability is related to how students develop new ideas (Sarah Sanders, 2016).

Media or multimedia in the learning process is quite important in improving the quality of the learning process, especially helping students to learn (Masykur et al., 2017; Mayer, 2017; Seabra \& Almeida, 2015). This is because the function and purpose of the media in learning include delivering messages to students from educators (Han \& Jiang, 2013; Santoso et al., 2016). Learning media can improve mathematical problem-solving abilities, mathematics learning achievement, students' interest in learning, and can even improve the quality of learning (Syazali, 2015). This is because the learning media are designed as attractive and effective as possible according to the condition of the students during the learning so that the learning process becomes more fun (Adi et al., 2018).

Mathematical creative thinking ability includes flexibility, fluency, originality, elaboration, and sensitivity (Kurniati, 2018; Septian et al., 2019). In using Android-based GeoGebra, students exercised flexibility in solving the questions given. Also, they were more dominant in fluency indicators. They can elaborate in great detail about how the mathematical equations, graphs, images, and how to change and shift points in the image so that the mathematical equation can be changed and vice versa.

In the first stage of the implementation of Android-based GeoGebra, students trained on using the Android-based GeoGebra, starting from installing to trying to use each menu. In the second stage, the teacher provided the material with the help of an Android-based GeoGebra. In the third stage, the students were divided into several groups. In the fourth stage, the students were given problems by the teacher. In the fifth stage, the students solved all problems in groups using Android-based GeoGebra. In the last stage, the students presented the results of their assignments with the help of Android-based GeoGebra.

The Android-based GeoGebra can directly influence the mathematical creative thinking ability and can increase students' interest in learning. Students feel happy and not bored with learning (Hallal et al., 2016; Septian et al., 2019). Motivation is also another determining factor for success in enhancing creative thinking ability and increasing technological abilities in solving mathematical problems (Saputra \& Fahrizal, 2019). The weaknesses of the Android-based GeoGebra are that students have to use mobile phones with high RAM. The buttons are prone to wrong clicks so that they shift themselves and make it difficult for students to use them.

\section{Students' Responses toward the Application of Android-based GeoGebra}

The responses to questionnaires were analyzed to see students' attitudes towards the learning process by applying Android-based GeoGebra in the experimental class. Questionnaires were given to students of the experimental class which consisted of 20 statements, specifically 11 positive statements and 9 negative statements.

The attitude scale questionnaire's statements were divided into several variables and indicators, namely three variables consisting of a scale of attitudes toward mathematics subjects, a scale of attitudes towards the application of Android-based GeoGebra, and a scale of attitudes towards questions of mathematical creative thinking ability. These variables were then subdivided into several indicators. 
Table 4. Overall Recapitulation of Students' Responses

\begin{tabular}{cccc}
\hline \multirow{2}{*}{ Indicator } & \multicolumn{2}{c}{ Recapitulation of Questionnaire Answers } & \\
\cline { 2 - 3 } & $\begin{array}{c}\text { Positive } \\
\text { Responses }(\%)\end{array}$ & $\begin{array}{c}\text { Negative } \\
\text { Responses }(\%)\end{array}$ & Decision \\
1 & 82,23 & 17,77 & Almost entirely positive \\
2 & 85,24 & 14,76 & Almost entirely positive \\
3 & 89,15 & 10,85 & Almost entirely positive \\
Average & 85,54 & 14,46 & Almost entirely positive \\
\hline
\end{tabular}

Based on Table 4, the average percentage of student responses was $85.54 \%$. It can be interpreted that the students' responses toward the application of Android-based GeoGebra were positive. The positive responses might be caused by interesting learning and transfer of knowledge from their peers (Tarigan \& Surya, 2017). Students become happy and positive in learning (Anggriani \& Septian, 2019).

\section{CONCLUSIONS}

Based on the results of the analysis and discussion, it can be concluded that the improvement of students' mathematical creative thinking ability through Android-based GeoGebra was better than ordinary learning. The students provided positive responses to the application of Android-based GeoGebra.

It is suggested for those who will conduct research using Geogebra for Android to master the media and the material better and deeper. Choose the appropriate mathematics material based on the media used so that the implementation process can be more effective.

\section{AUTHOR CONTRIBUTIONS STATEMENT}

AS is the author who came up with the overall research idea. RS and EM helped oversee the research project. All authors contributed to the interpretation of the results.

\section{REFERENCES}

Adi Widodo, S., Turmudi, T., Afgani Dahlan, J., Istiqomah, I., \& Saputro, H. (2018). Mathematical comic media for problem solving skills. International Conference on Advance \& Scientific Innovation, 101-108.

Ainurrizqiyah, Z., Mulyono, \& Sutarto, H. (2015). Keefektifan model PJBL dengan tugas creative mind-map untuk meningkatkan koneksi matematik siswa. Unnes Journal of Mathematics Education., 4(2), 172-179.

Alfian, M. H., Dwijanto, D., \& Sunarmi, S. (2017). Effectiveness of probing-prompting learning models with scaffolding strategy to mathematics creative thinking ability and enthusiasm. Unnes Journal of Mathematics Education, 6(2), 249-257.

Amalia, S. R., Purwaningsih, D., Widodo, A. N. A., \& Fasha, E. F. (2020). Model problem based learning berbantuan geogebra dan model realistic mathematics education terhadap representasi matematis siswa ditinjau dari gaya kognitif. Jurnal Elemen, 6(2), 157-166. 
Anggriani, A., \& Septian, A. (2019). Peningkatan kemampuan komunikasi matematis dan kebiasaan berpikir siswa melalui model pembelajaran IMPROVE. IndoMath: Indonesia Mathematics Education, 2(2), 105-116.

Arbain, N., \& Shukor, N. A. (2015). The effects of geogebra on students achievement. Procedia - Social and Behavioral Sciences, 172, 208-214.

Budiman, H., \& Ramdhani, S. (2017). Pengembangan bahan ajar matematika SMA berbasis geogebra versi android. Jurnal Science Tech, 3(2), 75-80.

Creswell, J. W. (2007). Research design: Qualitative, quantitative and mixed method aproaches. SAGE Publications, 203-223.

Firdausi, Y. N., \& Asikin, M. (2018). Analisis kemampuan berpikir kreatif siswa ditinjau dari gaya belajar pada pembelajaran model eliciting activities (MEA). FMIPA, Universitas Negeri Semarang, Semarang Usiyusrot, 1, 239-247.

Hallal, R., Hellmann, L., Sandmann, A., Carvalho, A. P., Reinaldo, F., \& Hotz, C. (2016). Geogebra in teaching of differential integral calculus I. Espacios, 37(20).

Han, X., \& Jiang, T. (2013). The application of energy-saving multimedia technology in higher mathematics teaching. Energy Education Science and Technology Part A: Energy Science and Research, 31(1), 223-226.

Hendriawan, M. A., \& Septian, A. (2019). Pengembangan JiMath sebagai multimedia pembelajaran matematika berbasis android untuk siswa sekolah menengah atas. IndoMath: Indonesia Mathematics Education, 2(1), 45-52.

Hockly, N. (2013). Mobile learning. ELT Journal, 67(1), 80-84.

Hu, R., Wu, Y. Y., \& Shieh, C. J. (2016). Effects of virtual reality integrated creative thinking instruction on students' creative thinking ability. Eurasia Journal of Mathematics, Science and Technology Education, 12(3), 477-486.

Johnson, R. B., \& Christensen, 1. (2014). Educational research: Quantitative, qualitative, and mixed approaches — Fifth edition. SAGE Publications.

Kurniati, N. (2018). Mengakses dan memonitor kemampuan berpikir kreatif matematis siswa kelas V sekolah dasar dalam pembelajaran matematika. Jurnal Prisma, 7(1), 99-106.

Legowo, B., Kusharjanta, B., Sutomo, A. D., \& Wahyuningsih, D. (2019). Increasing competency 4C using the G-Suite application for education. International Journal of Active Learning, 4(2), 168-171. 
Lince, R. (2016). Creative thinking ability to increase student mathematical of junior high school by applying models numbered heads together. Journal Of Education and Practice, 7(6), 206-212.

Maskur, R., Sumarno, Rahmawati, Y., Pradana, K., Syazali, M., Septian, A., \& Palupi, E. K. (2020). The effectiveness of problem based learning and aptitude treatment interaction in improving mathematical creative thinking skills on Curriculum 2013. European Journal of Educational Research, 9(1), 375-383.

Masykur, R., Nofrizal, N., \& Syazali, M. (2017). Pengembangan media pembelajaran matematika dengan macromedia flash. Al-Jabar: Jurnal Pendidikan Matematika, 8(2), 177.

Mayer, R. E. (2017). Using multimedia for e-learning. Journal of Computer Assisted Learning, 33(5), 403-423.

Muhammad, G. M., Septian, A., \& Sofa, M. I. (2018). Penggunaan model pembelajaran creative problem solving untuk meningkatkan kemampuan pemecahan masalah matematis siswa. Mosharafa: Jurnal Pendidikan Matematika, 7(3), 315-326.

Mulyani, M. A., Razzaq, A., Sumardi, W. H., \& Anshari, M. (2019). Smartphone adoption in mobile learning scenario. Proceedings of 2019 International Conference on Information Management and Technology, ICIMTech 2019, 208-211.

Nadz, T. F. (2013). Perbandingan peningkatan kemampuan penalaran matematis siswa yang memperoleh pembelajaran melalui metode problem based instruction (PBI) dengan metode konvensional. Mosharafa: Jurnal Pendidikan Matematika, 2(9), 191-202.

Nanang Supriadi. (2015). Pembelajaran geometri berbasis geogebra sebagai upaya meningkatkan kemampuan komunikasi matematis Siswa Madrasah Tsanawiyah (MTs). Al-Jabar: Jurnal Pendidikan Matematika, 6(2), 1-14.

Noer, S. H. (2011). Kemampuan berpikir kreatif matematis dan pembelajaran matematika berbasis masalah open-ended. Jurnal Pendidikan Matematika, 5(1), 104-111.

Nurlenasari, N., Lidinillah, D. A. M., Nugraha, A., \& Hamdu, G. (2019). Assessing 21st century skills of fourth-grade student in STEM learning. Journal of Physics: Conference Series, 1318(1).

Özyaprak, M. (2016). The effectiveness of SCAMPER technique on creative thinking skills. Journal for the Education of Gifted Young Scientists, 4(1), 31-40. 
Pramuditya, S. A., Noto, M. S., \& Purwono, H. (2018). Desain game edukasi berbasis android pada materi logika matematika. JNPM (Jurnal Nasional Pendidikan Matematika), 2(2), 165.

Pratama, U. N., \& Haryanto, H. (2018). Pengembangan game edukasi berbasis android tentang domain teknologi pendidikan. Jurnal Inovasi Teknologi Pendidikan, 4(2), 167184.

Purwanti, R. D., Pratiwi, D. D., \& Rinaldi, A. (2016). Pengaruh pembelajaran berbantuan geogebra terhadap pemahaman konsep matematis ditinjau dari gaya kognitif. Al-Jabar: Jurnal Pendidikan Matematika, 7(1), 115-122.

Putra, D. W., Nugroho, A. P., \& Puspitarini, E. W. (2016). Game edukasi berbasis android sebagai media pembelajaran untuk anak usia dini. Jurnal Informatika Merdeka Pasuruan, $1(1), 46-58$.

Rudyanto, H. E. (2016). Model discovery learning dengan pendekatan saintifik bermuatan karakter untuk meningkatkan kemampuan berpikir kreatif. Premiere Educandum: Jurnal Pendidikan Dasar dan Pembelajaran, 4(1), 41-48.

Santoso, H. B., Schrepp, M., Yugo Kartono Isal, R., Utomo, A. Y., \& Priyogi, B. (2016). Measuring user experience of the student-centered E-learning environment. Journal of Educators Online, 13(1), 1-79.

Sanusi, A. M., Septian, A., \& Inayah, S. (2020). Kemampuan berpikir kreatif matematis dengan menggunakan education game berbantuan android pada barisan dan deret. Mosharafa: Jurnal Pendidikan Matematika, 9(September), 511-520.

Saputra, E., \& Fahrizal, E. (2019). The development of mathematics teaching materials through geogebra software to improve learning independence. Malikussaleh Journal of Mathematics Learning (MJML), 2(2), 39-44.

Sarah Sanders. (2016). Critical and creative thinkers in mathematics classrooms. Journal of Student Engagement : Education Matters, 6(1), 19-27.

Seabra, C., \& Almeida, A. M. (2015). Project management on multimedia projects: preliminary results on communication, interaction and team work dynamics. Procedia Computer Science, 64, 816-823.

Septian, A. (2017). Penerapan geogebra untuk meningkatkan kemampuan pemecahan masalah matematis mahasiswa program studi pendidikan matematika Universitas Suryakancana. PRISMA, 6(2), 180-191. 
Septian, A., Darhim, \& Prabawanto, S. (2020). Geogebra in integral areas to improve mathematical representation ability geogebra in integral areas to improve mathematical representation ability. Journal of Physics: Conference Series, 1613, 1-7.

Septian, A., Inayah, S., Suwarman, R. F., \& Nugraha, R. (2019). GeoGebra-assisted problem based learning to improve mathematical problem solving ability. Advances in Social Science, Education and Humanities Research, 467, 67-71.

Septian, A., Komala, E., Komara, K. A., Suryakancana, U., Suryakancana, U., \& Kreatif, K. B. (2019). Pembelajaran dengan model creative problem solving (CPS) untuk meningkatkan kemampuan berpikir kreatif matematis siswa. Prisma, 8(2), 182-190.

Sharples, M., \& Pea, R. (2014). The Cambridge Handbook of the Learning Sciences, Second Edition . Cambridge University Press.

Sianturi, M., \& A, N. (2019). The effects of smartphone on studentsâ $€^{\mathrm{TM}}$ learning at National Dong Hwa University. Journal of Education and Vocational Research, 9(2), 9-14.

Sriwongchai, A. (2015). Developing the mathematics learning management model for improving creative thinking In Thailand. International Education Studies, 8(11), 77-87.

Sugiarni, R., Alghifari, E., \& Ifanda, A. R. (2018). Meningkatkan kemampuan spasial matematis siswa dengan model pembelajaran problem based learning berbantuan geogebra. KALAMATIKA Jurnal Pendidikan Matematika, 3(1), 93-102.

Sugilar, H. (2013). Meningkatkan kemampuan berpikir kreatif dan disposisi matematik siswa madrasah tsanawiyah melalui pembelajaran generatif. Infinity Journal, 2(2), 156-168.

Sundari, J. (2017). Pengaruh model pembelajaran kooperatif tipe make a match terhadap kemampuan komunikasi matematis siswa. JKPM (Jurnal Kajian Pendidikan Matematika), 2(2), 227-234.

Suripah, S., \& S. A. (2017). Kemampuan berpikir kreatif matematis mahasiswa dalam menyelesaikan akar pangkat persamaan kompleks berdasarkan tingkat kemampuan akademik. Jurnal Pendidikan Matematika, 12(2), 149-160.

Syazali, M. (2015). Pengaruh model pembelajaran creative problem solving berbantuan media maple 11 terhadap kemampuan pemecahan masalah matematis. Al-Jabar, 6(1), 101-115.

Tarigan, F. A. P., \& Surya, E. (2017). The application of cooperative learning model of jigsaw type to increase activity and student learning results in learning phytagoras theorem. IJARIIE: International Journal of Advance Research and Innovative Ideas in Education, 3(3), 882-891. 
Wijayanti, S., \& Sungkono, J. (2017). Pengembangan perangkat pembelajaran mengacu model creative problem solving berbasis somatic, auditory, visualization, intellectually. Al-Jabar : Jurnal Pendidikan Matematika, 8(2), 101-110.

Zaheer, S., Butt, S. M., Anatolyevna, G. V., \& Salmani, H. (2018). Do mobile technology in the classroom really improve learning outcomes?. International Journal of Evaluation and Research in Education (IJERE), 7(3), 188-193. 